\title{
Surface Modification of Multilayer Coatings Ti-Al-Cr and Hydroxyapatite on Calcium Phosphate Cement with Sol-Gel Method
}

\author{
Atia N. Sidiqa ${ }^{1}$, Nina Djustiana ${ }^{2}$, Bambang Sunendar ${ }^{3}$, Renny Febrida ${ }^{3}$ \\ ${ }^{1}$ Department of Dental Materials, Medical Faculty, Universitas Jenderal Achmad Jani, Cimahi 40533, Jawa Barat, \\ Indonesia \\ ${ }^{2}$ Department of Dental Material, Faculty of Dentistry, Universitas Padjajaran, Bandung 40132, Jawa Barat, \\ Indonesia \\ ${ }^{3}$ Laboratory of Material Processing, Department of Engineering Physics, Institute of Technology Bandung, Bandung \\ 40132, Jawa Barat, Indonesia \\ Correspondinge-mail to: atia_ns@yahoo.co.id
}

\begin{abstract}
Implan gigis based on metal still has weaknesses. New development is currently developed with the surface modification of multilayer coatings Ti-Al-Cr and hydroxyapatite on calcium phosphate cement (CPC) for Implan gigi application. Objective: To analize the thickness of multilayer coating alloy Ti-Al-Cr and hydroxyapatite on CPC synthesis by sol-gel method. Methods: Scanning electron microscopy (SEM) was conducted to analyze the thickness and morphology of microstructure layer formed on CPC. Result: SEM showed that coating Ti-Al-Cr on CPC successfully formed $1 \mu \mathrm{m}$ of thickness and showed $10 \mu \mathrm{m}$ of hydroxyapatite. Conclusion: The innovation of modification surface multilayer coatings Ti-Al-Cr and hydroxyapatite on CPC was successfully done by sol-gel method with a variety thickness.
\end{abstract}

\begin{abstract}
ABSTRAK
Modifikasi permukaan pada semen kalsium fosfat dengan multilapis Ti-Al-Cr dan hidroksiapatit dengan metode sol-gel. Implan gigi berbahan dasar logam paduan titanium Ti-Al-Cr dilapisi hidroksiapatit diketahui masih memiliki kelemahan. Oleh karena itu dilakukan pengembangan dengan modifikasi permukaan dengan multilapis Ti-Al-Cr dan hidroksiapatit pada semen kalsium fosfat untuk aplikasi implan dental. Tujuan: Penelitian ini bertujuan untuk melihat ketebalan multilapis logam paduan Ti-Al-Cr dan hidroksiapatit pada CPC dengan sintesis metode sol-gel. Metode: Analisis ketebalan multilapis dan mikrostruktur logam paduan Ti-Al-Cr dan hidroksiapatit pada CPC dilakukan dengan menggunakan Scanning Electron Microscopy (SEM). Hasil: SEM menunjukkan lapisan logam paduan Ti-Al-Cr pada CPC berhasil dibentuk dengan ketebalan 1 $\mu \mathrm{m}$ sedangkan lapisan hidroksiapatit yang terbentuk adalah $10 \mu \mathrm{m}$. Simpulan: Modifikasi permukaan dengan multilapis Ti-Al-Cr dan hidroksiapatit pada CPC berhasil dilakukan dengan menggunakan metode sol-gel dengan ketebalan bervariasi.
\end{abstract}

Key words: calcium phosphate cement, coating, hydroxyapatite, sol-gel, Ti-Al-Cr

\section{PENDAHULUAN}

Implan gigi yang berkembang saat ini adalah logam paduan titanium..$^{1-3}$ Logam paduan titanium memiliki lapisan oksida pada permukaannya. Lapisan oksida bersifat biokompatibel sehingga dapat terjadi proses matriks tulang pada permukaan implan gigi secara in vivo melalui proses oseointegrasi. ${ }^{1,3}$ Beberapa penelitian menunjukkan bahwa bioaktifitas permukaan logam titanium tidak cukup untuk membentuk pertumbuhan jaringan tulang sehingga menghasilkan fiksasi yang kurang baik terhadap jaringan. ${ }^{1,3,4}$ Oleh karena itu dilakukan penelitian mengenai variasi berbagai macam bahan dasar implan untuk menghasilkan ikatan yang lebih baik antara implan dengan tulang. ${ }^{5,6}$ Salah satu pengembangan yang dilakukan adalah dengan menggunakan implan gigi berbahan dasar apatit, yaitu semen kalsium fosfat yang dapat menghasilkan hidroksiapatit yang bersifat bioaktif bila direndam pada larutan simulated body fluid (SBF)., 2,78 
Penelitian ini dilakukan untuk menganalisa ketebalan yang terbentuk dari coating berlapis alloy $\mathrm{Ti}-\mathrm{Al}-\mathrm{Cr}$ dan hidroksiapatit pada CPC yang disintesis dengan metode sol-gel.

\section{METODE}

Spesimen adalah bubuk semen kalsium fosfat dicampurkan dengan larutan kitosan 5\%. Perbandingan rasio bubuk:larutan yang digunakan pada pencampuran ini adalah 3:1. Perbandingan ini diperoleh melalui percobaan pada penelitian pendahuluan. Bubuk dan larutan kemudian diaduk hingga homogen menggunakan spatula pada kaca preparat. Pasta semen kalsium fosfat yang telah homogen kemudian dimasukkan pada cetakan dengan diameter $10 \mathrm{~mm}$ dan tinggi $5 \mathrm{~mm}$.

Perendaman spesimen pada larutan logam paduan Ti-Al-Cr ini dilakukan merendam spesimen secara langsung pada larutan logam paduan Ti-Al-Cr selama 24 jam, lalu spesimen dikeringkan kemudian dibakar pada tungku Nitrogen. Spesimen yang telah dibakar kemudian didinginkan hingga suhu ruang. Spesimen lalu direndam pada larutan SBF selama 5 hari dengan temperatur $36^{\circ} \mathrm{C}$.

\section{HASIL}

Karakterisasi mikrostruktur spesimen dengan menggunakan scanning electron microscope (SEM, JEOL) SEM merek JEOL di Pusat Penelitian dan Pengembangan Geologi Kelautan (PPGL). Karakterisasi dengan SEM ini bertujuan untuk melihat struktur, morfologi ketebalan coating logam paduan Ti-Al-Cr dan hidroksiapatit yang terbentuk pada spesimen. Gambar-an mikrostruktur hasil karakterisasi SEM pada spesimen semen kalsium fosfat coating berlapis Ti-Al-Cr memperlihatkan adanya lapisan coating logam paduan Ti-Al-Cr dengan ketebalan $1 \mu \mathrm{m}$ (Gambar 3). Gambaran mikrostruktur hasil karakterisasi SEM pada spesimen semen kalsium fosfat coating berlapis Ti-Al-Cr yang telah direndam larutan SBF selama 5 hari sehingga menghasilkan lapisan terluar berupa hidroksiapatit memperlihatkan adanya lapisan coating dengan ketebalan $10 \mu \mathrm{m}$ dengan lapisan hidroksiapatit yang terbentuk lebih tebal daripada coating logam paduan Ti-Al-Cr (Gambar 4).

\section{PEMBAHASAN}

Semen kalsium fosfat (CPC) adalah semen tulang dengan bahan dasar apatit kalsium dan fosfat yang dapat bertransformasi dari bentuk pasta menjadi solid. Semen kalsium fosfat disintesis dari tetracalcium phosphate (TTCP) dan dicalcium phosphate anhydrate (DCPA) dengan perbandingan molar yang sama.9-11

Semen kalsium fosfat merupakan material unik karena memiliki kemampuan osteokonduktif, biokompatibel, bioresorbable, dan mudah dibentuk sebagai bone filler pada rongga tulang dengan ukuran yang kecil., ${ }^{9} 10,12 \mathrm{Se}-$ men kalsium fosfat memiliki komposisi yang menyerupai tulang dan gigi. ${ }^{10}$ Namun, sifat mekanisnya belum cukup kuat untuk menerima beban kunyah sehingga diperlukan bahan tambahan lain yang dapat memberikan kekuatan pada implan berbasis apatit ini. ${ }^{2,8,10}$

Penambahan logam paduan Ti-Al-Cr dengan teknik coating berlapis dilakukan untuk menambah kekuatan mekanis implan semen kalsium fosfat. Logam paduan Ti-Al-Cr banyak digunakan untuk aplikasi medis seperti implan gigi karena memiliki sifat yang menguntungkan seperti, memiliki modulus elastisitas yang dapat diterima oleh jaringan tulang, resistensi korosi, biokompatibilitas yang baik terhadap jaringan dibandingkan dengan jenis logam yang lainnya, dan reaksi alergi yang jarang terjadi. ${ }^{1-3}$

Lapisan terakhir berupa hidroksiapatit dihasilkan melalui metode biomimetik, yaitu dengan cara merendam implan berbasis apatit ini pada larutan SBF. Hidroksiapatit yang terdapat pada permukaan Implan terluar merupakan modifikasi permukaan yang bertujuan untuk menambah bioaktifitas perlekatan antara implan dan jaringan tulang, sehingga dihasilkan perlekatan mekanis dan biologis yang baik. ${ }^{10}$

Metode sol-gel merupakan salah satu metode yang dikembangkan yang menghasilkan berbagai jenis material karena memiliki banyak keuntungan. Beberapa keuntungannya adalah kemudahan untuk mengatur komposisi dan sintesis yang dapat dilakukan pada temperatur rendah. Keuntungan lain dari teknologi solgel adalah dapat menghasilkan lapisan yang homogen, murni, dan stoikiometris akibat percampuran dengan skala molekuler. Temperatur pembakaran yang rendah karena ukuran partikel kecil dan luas permukaan besar, sehingga memungkinkan diperolehnya partikel ukuran nano yang homogen, serta peralatan yang relatif sederhana. ${ }^{13}$

Teknik ini terdiri dari beberapa tahapan pengerjaan, yaitu penyiapan larutan prekursor, hidrolisis untuk proses gelasi, aging, dan drying atau sintering seperti terlihat pada Gambar 1. Prekursor yang digunakan dapat berupa senyawa anorganik atau metal organik. ${ }^{13}$ Teknik sol-gel memiliki dua tahapan reaksi yaitu reaksi hidrolisis dan reaksi kondensasi atau polimerisasi. Reaksi hidrolisis merupakan suatu proses dimana terjadi reaksi antara senyawa prekursor (senyawa awal yang dibutuhkan untuk mendapatkan senyawa yang diinginkan pada proses sintesis nanopartikel dengan metode sol-gel $)^{15,16}$ dengan air $\left(\mathrm{H}_{2} \mathrm{O}\right)$, sehingga meng- 


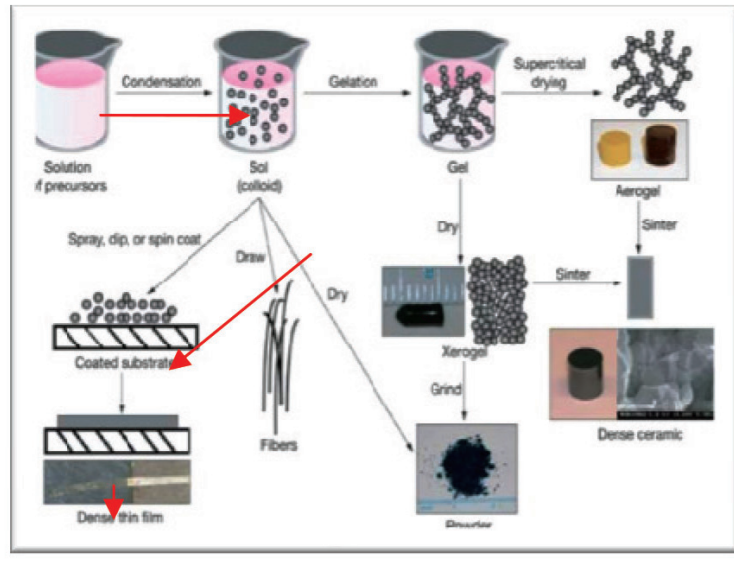

Gambar 1. Skematik Metode sol-gel ${ }^{18}$

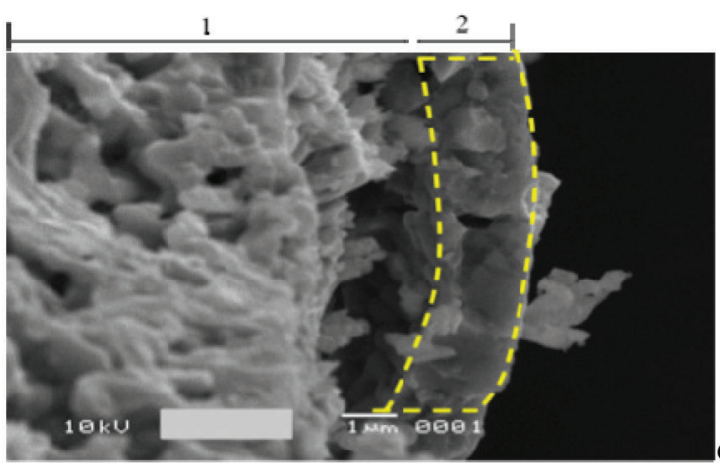

Gambar 2. Hasil SEM pada Semen Kalsium Fosfat Coating berlapis Ti-Al-Cr: (1) semen kalsium fosfat (CPC), (2) logam paduan $\mathrm{Ti}-\mathrm{Al}-\mathrm{Cr}$

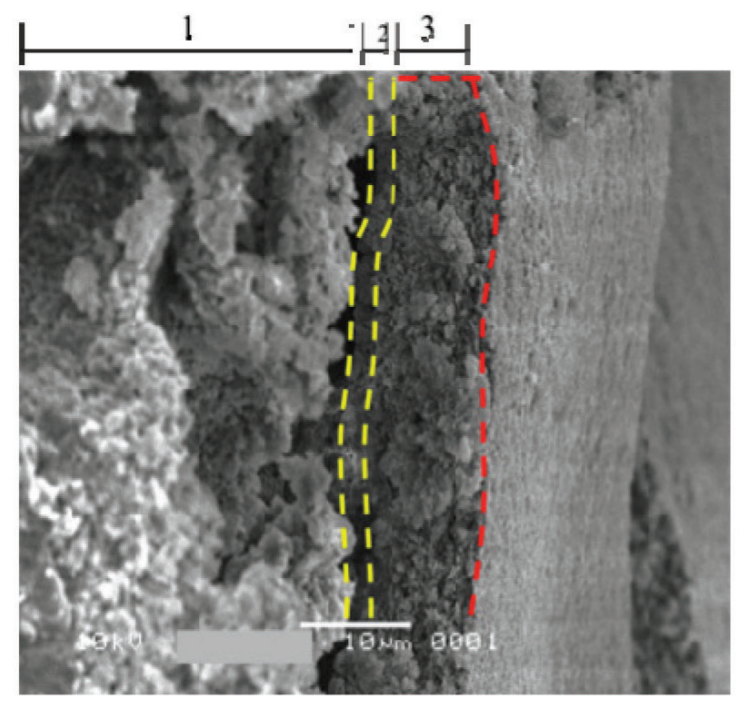

Gambar 3. Hasil SEM pada semen kalsium fosfat coating Ti-Al-Cr dan HA: (1) Semen kalsium fosfat (CPC), (2) Logam paduan Ti-Al-Cr, (3) Hidroksiapatit (HA) hasilkan senyawa metal hidroksida. Proses kondensasi merupakan proses dimana metal hidroksida yang telah terbentuk pada proses hidrolisis saling berikatan membentuk rantai oksida dan menghasilkan senyawa metal oksida (Gambar 1). ${ }^{17}$

\section{SIMPULAN}

Sintesis modifikasi permukaan coating berlapis TiAl-Cr dan hidroksiapatit pada semen kalsium fosfat (CPC) berhasil terbentuk. Coating berlapis logam paduan Ti-Al-Cr dan hidroksiapatit pada CPC yang disintesis dengan metode sol-gel menghasilkan lapisan terluar berupa hidroksiapatit memperlihatkan adanya lapisan coating dengan ketebalan $10 \mu \mathrm{m}$ dengan lapisan hidroksiapatit yang terbentuk lebih tebal daripada coating logam paduan Ti-Al-Cr.

\section{DAFTAR PUSTAKA}

1. Founda MFA, Nemat A, Gawish A, Baiuomy AR. Does the coating of titanium Implan s by hydroxyapatite affect the elaboration of free radicals. An experimental study. Aust J Basic \& Appl Sci. 2009;3:1122-9.

2. Niinomi M. Recent research and development in titanium alloys for biomedical applications andhealthcare goods. J Sci Tech Adv Mater. 2003;4:44554.

3. Lobato JV, Hussain NS, Lopes MA. Clinical applications of titanium Implan gigis coated with glassreinforced hydroxyapatite composite $\left(\right.$ Bonelike $\left.^{\circledR}\right)$. Int J Nanomanufacturing. 2008;2:135-48.

4. Truhlar RS, Harold FM, Shigeru O. Implant surface coating and bone quality-related survival outcomes through 36 months post-placement of root form endosseous dental implant. Ann Periodontol. 2000;5:109-18.

5. Conner KA, Sabatini R, Mealey BL, Takacs UJ, Mills MP, Cochran DL. Guided bone regeneration around titanium plasma sprayed, acid-etched, and hydroxyapatite-coated implants in the canine model. J Periodontol. 2003;74:658-68.

6. Mueller WD, Gross U, Fritz T, Voigt C, Fischer $\mathrm{P}$, Berger $\mathrm{G}$, et al. Evaluation of the interface between bone and titanium surface being blasted by alumunium oxide or bioceramic particles. Clin Oral Implant Res. 2003;14:349-56.

7. Simon V, Muresan D, Popa C, Simon S. Microscopic analysis of sintered titanium-hydroxyapatite Implan materials. J Mater Sci. 2001;12:471-8.

8. Khasaba RM, Mervet MM, Donald JM, Frederick AR, Norman BC, James B. Polymeric-calcium phosphate cement composites-material properties: in vitro and in vivo investigations. Int $\mathbf{J}$ Biomat. 2010;9:1-14. 
9. Xu HHK, Quinn JB, Takagi S, Chow LC. Processing and properties of strong and non-rigid calcium phosphate cement. J Dent Rest. 2002;81:219-224.

10. Fukase Y, Eanes ED, Takagi S. Chow LC, Brown WE. Setting reactions and compressive strengths of calcium phosphate cements. J Dent Rest. 1990;69:1852-6.

11. Santos LA, Luci CO, Eliana CSR, Raul GC, Anselmo OB, et al. Fiber reinforced calcium phosphate cement. J Int Soc Artificial Organs. 2000;24:212-6.

12. Pramanik M, Mishra D, Banerjee I, Maiti TK, Bhargava $P$, Pramanik P. Chemical synthesis, characterization, and biocaompatibility study of hydroxyapatite/ chitosan phosphate nano-composite for bone tissue engineering applications. J Int Biomat. 2008:1-8.

13. Chu, TMG, JW. Halloran, SJ. Hollister, SE. Feinberg. Hydroxyapatite Implan with design internal architecture. J Mater Sci. 2001;12:471-8.
14. Goncalves JE, Filho UPR, Franco DW, Gushikem Y. Adsorption of peroxide on the surface of silicatitania mixed oxide obtained by the sol-gel processing method. Eclet Quim. 2007;32:41-45.

15. Dimitriev Y, Ivanova Y, Iordanova R. History of solgel science and technology (review). J Uni Chem Technol Metal. 2009;43:181-92.

16. Bastomi T. Sintesis Serbuk $\alpha$-alumina skala submikron dengan metode precursor process. Proceeding of Seminar Nasional Keramik, Balai Besar Keramik, Bandung; 2009: p. 34-5. Indonesian.

17. Evelyna A, Purwasasmita BS, Djustiana N, Hasratiningsih Z. Self synthesis Al-Si-Zr nanoparticle filler and it's microstructure Characterization for resin dental restorative materials. Proceeding of IDA-FDI Join Meeting. Balikpapan. 2010: p.1-9. 